\title{
A Review of Privatization and Public Enterprises Reform in Nigeria
}

\author{
D. O. Adeyemo \\ Adekunle Ajasin University \\ E-Mail: dadeyemo2002@yahoo.com \\ Adeleke Salami \\ Adekunle Ajasin University \\ E-Mail: saladeleke@yahoo.com
}

\begin{abstract}
Public enterprises in Nigeria were established to propel socio-economic development and to guard against the control of the economy from foreign domination and exploitation. This accounts for why a larger proportion of the national budget has been voted for the creation and sustenance of public enterprises. In spite of this, the performance of public enterprises has been replete with varying contradictions. The public enterprises reform was an integral part of the Structural Adjustment Programme (SAP) in 1986. This paper tries to review the public enterprises reform and make suggestions for the sustainability of the reform in Nigeria.
\end{abstract}

Keywords: Public, Enterprises, Reform, Privatization, Commercialization

\section{INTRODUCTION}

There appears to be no universally agreed definition among scholars regarding the conceptual meaning of public enterprises. According to Laleye (1985) the bewildering number and types of the organizations called 'public enterprises' their different contents and the rationale for which they are set up accounts for lack of authoritative and generally acceptable definition of public enterprises. Sosna (1983) opined that there are many reasons why in developed capitalist countries, there is no single standard definition of public enterprises. Public enterprises were established at different periods, and each epoch naturally brought forth the types of public 
enterprises most clearly matching its own conditions.

It is therefore believed that the variation in definition are informed by the ideological, values, interests, dispositions and circumstances that brought public enterprises into existence.

Whatever the controversy and the lack of uniformity might conjure up, we would however review the viewpoint of some scholars of public enterprises. For instance, Efange (1987) define public enterprises or parastatal as institutions or organizations which are owned by the state or in which the state holds a majority interest, whose activities are of a business in nature and which provide services or produce goods and have their own distinct management.

Obadan (2000), Obadan \& Ayodele (1998) defined public enterprises as organizations whose primary functions is the production and sale of goods and/or services and in which government or other government controlled agencies have no ownership stake that is sufficient to ensure their control over the enterprises regardless of how actively that control is exercised.

In another dimension Nellis (1986) refuses to give a precise definition of public enterprise, but only adduced reasons for its creation. He observed that there are many reasons that explain why African states have created and sustained public enterprises.

"Institutions and pre-dispositions inherited from centralized interventionist colonial regimes; a tendency to associate liberal capitalism with colonialism and imperialism; the post war ascendancy of leftist/statist political ideologies; the apparent absence or embryonic nature of the indigenous private sector; the conversion of failing private enterprises into public enterprises to forestall increases in employment; the attractiveness of public enterprises to politicians who use them as patronage mechanisms to distribute jobs to both the mighty and the minor - these are but some of the more important historical economic, social and political factors which have led almost every African state to create large public enterprise sector".

The basic reason for establishing public enterprises in all economies has been to propel development. Hanson (1972) reflecting on Turkey, Mexico, India and Nigeria noted that the establishment of public enterprises is premised on what he considered as obstacles to economic development in the post independence states. It is also instructive to note that in Nigeria like many developing countries, public enterprises are used as employers of last resort. According to Hemming \& Mansor (1988a) it is noted that state owned enterprises enable governments to pursue goals of social equity that the market ordinarily ignores. Similarly, Ugorji (1995) observed that public 
enterprises have also been established for political reasons. Many government undertakings are used to provide jobs for constituents, political allies, and friends. The location of public enterprises and the distribution of government employment have further been defended on the need to maintain "federal character" and promote national integration.

Other factors that accelerated the growth of Nigeria's public sector was the indigenization policy of 1972 as enacted by the (Nigerian Enterprises Promotion Decree). It was designed to control the commanding heights of the economy. The policy further provided the much needed legal basis for extensive government participation in the ownership and control of significant sectors of the economy. It also reinforced the increasing dominant of the public sector in the economy.

In spite of the impetus given to public enterprises especially in Nigeria some criticisms are leveled against them. Their problems are so enormous that even left the Nigerian public in a state of great disillusionment. These criticisms vary from lack of profitability and reliance on large government subsidies.

Ogundipe (1986) once argued that between 1975 and 1985, government capital investments in public enterprises totaled about 23 billion Naira. In addition to equity investments, government gave subsidies of N11.5 billion to various state enterprises. All these expenditures contributed in no small measure to increased government expenditures and deficits.

Similarly, public enterprises suffer from gross mismanagement and consequently resulted to inefficiency in the use productive capital, corruption and nepotism, which in turn weaken the ability of government to carry out its functions efficiently (World Bank, 1991). There are avalanche of literatures that point to the problems of public enterprises especially in Nigeria. They include Ajakaiye (1990), Ayodele (1988), Okigbo (1998), Kalu (1999), Obadan (2000), Sanusi (2001). All these scholars have developed growing interest on the conception and functions of public enterprises and of the need for their reform.

\section{THEORETICAL AND LITERATURE REVIEW}

In both developed and developing countries, privatization and in some cases commercialization have grown in popularity and acceptability. It has also become an important instrument that government can use to promote economic development, improve the production and distribution of goods and services, stream line government structure, and reinvigorate industries controlled or managed by the state. ( Rondinelli and Iacono 1996). 
Privatization has become an acceptable paradigm in political economy of states. It is a strategy for reducing the size of government and transferring assets and service functions from public to private ownership and control. Privatization is based on four core beliefs (Ugorji, 1995):

1. Government is into more things than it should be. It is intruding into private enterprise and lives ;

2. Government is unable to provide services effectively or efficiently;

3. Public officials and public agencies are not adequately responsive to the public; and

4. Government consumes too many resources and thereby threatens economic growth.

On the theoretical plane, four distinctive schools of thought have tried to explain variations of policies applicable to privatization. First, there is the free-market ideology of the liassez-faire classical economic theory, which favours the unleashing of the competitive profit motive by emancipating free- market pricing from the interfering hands of state regulation (Samuelson; 1980). It argues that the character of the traders and that of the sovereign are inconsistent, that public administration was negligent and wasteful because public employees have no direct interest in the outcome of their actions. Privatization according to this theory would reap the advantages of the market system and competition, namely effectiveness, productivity, and efficient service. This trend will also strengthen market forces with some degree of deregulation, economic liberalization, relaxation of wage and price controls (Ugorji, 1995).

The second school of thought is the 'public choice approach to policy and political analysis. This approach tries to explains the behaviour and provide sets of standards about what the government does. The theory assumes that people are rational, utility-maximizing individual and that economic efficiency becomes the prime criterion for judging the political, social and economic system. Consequently, all the government does is judged in terms of the impact on individual choice and economic efficiency.

Public choice posits that the nature of goods and services determines whether they should be provided through the market system or through the public sector. The point is that private goods should be provided by the market whereas government should provide public goods. In sum the theory posited that where public goods provide separable private benefits (e.g. education) the recipients of the private benefit should be required to pay for net portion of the cost that represents the private benefit 


\section{(Ostrum \& Ostrum 1991).}

Like many other developing countries, Nigeria government has been seen over the years, as having gone beyond the effective and efficient provision of public goods to the provision of private goods. And it has not only failed on both scores, it has also overextended itself in its public sector commitments through the establishment of too many state enterprises and through continued financial support of those enterprises that have continued to lose money. This scenario has created unprecedented high level of public sector deficits financed mostly through heavy external borrowing, high inflation rates and balance of trade deficits. The end product of this tendency is that privatization would enable government to cut public expenditures and reduce its involvement in activities the private sector can undertake (Ugorji, 1995).

Thirdly, populist approach on the other hand argues for allowing citizens more choices in terms of sources of services they purchase. This position is geared towards community enterprises that could be more responsive to the needs of the people they serve. Empowered is seen as the other half of the equation. As privatization compels government to embrace the efficiency and effectiveness of the market, it must also embrace the community.

The fourth school of thought is the pragmatist, which advocates alternative approaches to enable the government to provide services with the highest possible efficiency. They believed that private sector may operate efficiently in resource allocation and service provision; they held that some functions are essential to the public purpose. Such functions like the provision public transportation, education and health should be retained by the government and operated on the basis of the advantages that characterize the market operation. The Nigeria's commercialization policy is in consonant with this school of thought.

Arising from the above, empirical evidences points to the global acceptability of privatization policy. Rondinelli \& Iacono (1996) viewed that Latin American countries such as Chile and Argentina had transferred large-state controlled telecommunications, railways, power and energy, airline, mining and oil and petroleum industries to private ownership or management during the 1970s \& 1980s. Mexico has also privatized enterprises in industry from agricultural business, airlines, mining, metals, pharmaceuticals, real estate, hotels and automotive parts to fish processing, fertilizers telecommunications and banking.

In Asia, private sector had started to participate in providing urban shelter, social services and physical infrastructure. In the 1980s in the Republic of Korea, Indonesia, Thailand and the Philippines sold or solicited private investment in state-owned 
manufacturing and public service enterprises. In some Communist countries such as Poland, Hungary, the Czech Republic, and some of the republics of the former Soviet Union, the government privatized some state-owned enterprises after the collapse of the communist regimes.

The success story of privatization reform were also recorded in western industrial countries such as United Kingdom, France, Italy, Spain, Austria, Sweden, Portugal, Netherlands, Germany, the United States, Japan and Canada. These countries have reformed their state-owned enterprises to achieve administrative and economic objectives. Countries of the developing world are not left out of this crusade of privatization.

Quite a number of public sector enterprises are operated without respect to financial costs or returns. Not all such investment is expected to yield immediate financial returns as some of the benefits are social rather than private in character that is, they accrue to society as a whole rather than exclusively to particular or denominated individuals (Okigbo, 1998). Some services yield benefit to the community generally as well as to individual citizens. In the production of most of other private consumer goods and services, it is easy to determine whether the outlays are justified or not lay virtue of the financial returns to investment. It suggests therefore that the production methods must be efficient and that the price change should at least cover the costs of operations. Therefore, commercialization which differs from privatization is one of the policy thrust of the reform of state-owned enterprises.

Operationally, Nigerian commercialization and privatization Decree No 25 of 1988 defines commercialization as "the reorganization of enterprises wholly and partly owned by the government in which such commercialized enterprises shall operate as profit-making ventures and without subvention from government”.

The decree also distinguishes between full and partial commercialization. The fully commercialized enterprises are expected to operate on a commercial basis to raise fund from the capital market without any form of government guarantee, such enterprises are expected to use private sector procedures in the running of their business. It is expected that such enterprises would require no government subvention because of their high social service content; their operation cannot be left to individual shareholders. A typical example is the Nigerian National Petroleum Corporation (NNPC) which is a pivot to the national economy.

Partial commercialization is those enterprises with high social service component. Such enterprises are expected to generate enough revenue to cover their 
operating expenditures. The government may therefore give them subventions to finance their capital-intensive projects. It should be noted that both full and partial commercialization does not require that government would divest her equity holdings.

Essentially commercialization exercise also calls for a "performance contract" to govern the post commercialization financial relationship between government and the commercialized enterprises.

The contract requires:

1. Specifying long-term objectives of the enterprise;

2. Establishing agreed (between the enterprise and the government) performance criteria;

3. Having an agreed level of enterprises performance; and

4. Having a performance bond that specifies penalties for not meeting agreed levels of performance or rewards for surpassing them.

In sum, a performance contract establishes a two-way relationship between the government and commercialized enterprises.

\section{MODALITIES FOR PRIVATIZATION}

Kalu (1999) discusses the essential macroeconomic reforms for achieving a good environment for privatization which include the following essential elements:

1. Structural Adjustment Policies. These are policies designed to correct macroeconomic trends which are preventing the economy from moving in the direction that is optimal in relation to the dynamic comparative advantage of the economy. Thus, putting in place appropriate private economic policies in such areas as exchange and interest rates management should result in improved resource allocation, employment, incomes and resource mobilization. This would also involve other economic stabilization measures such as the reduction of balance of payments deficit, debt rescheduling, and proper regulation of money supply, reduction of subsidies and control of speculative money flow as well as overall wage policy.

2. Trade and investment reform policies: These includes programs for export promotion, foreign direct investment, exchange rate adjustments and reduction of investment restrictions and trade barriers, as well as the result of multilateral negotiations designed to promote fair trading and anti-trust behavior.

3. Security-including the restructuring of the police force: This can be achieved by conducting intensive training courses for young and able police officers whose services are no longer needed. Consequently, the ratio of a policeman to 1,000 
Nigerians should significantly increase. Without a secure environment, the investors will be scared to invest.

4. Institutional development policies: These includes programs to support the creation and strengthening of an effective system of property rights, financial rights, financial institutions, and labor markets, social and legal institutions and adjudicate or resolve conflicts effectively together with channels for marketing and distribution.

5. Private sector development programs: Including incentives and support for developing small and medium-sized enterprises, restructuring large companies and attracting investments in domestic industries from multinational corporations.

Kalu (1999) concluded that the above five fundamental elements of economic reforms and the institutional capacities that must be strengthened to support privatization. It is also of importance to pursue then to the logical conclusion in order for privatization program to succeed.

In summary therefore, effective transition to a market economy which should necessarily underscore privatization must encompass the set of reforms, which embraces measures on freeing prices, trade and entry to markets from state control and intervention. This implies complete liberalization, decentralization and macroeconomic stabilization.

As at the end of 2005, over 40 enterprises have been privatized. While over 30 enterprises have been commercialized. The privatization / commercialization exercise was not limited to Federal Government. It is important to add that all the 36 State Governments have divested their interests in several companies through sales of shares in some companies or outright sales of others.

The experience with most privatized enterprises tallied with expectation. The privatized enterprises in Nigeria were able to achieve the desired objectives, there were few exemption however. The table in the appendix revealed that majority of the privatized enterprises are doing well such that their prices has appreciated in the capital market. Unipetrol (now Oando) recorded the highest capital appreciation of 76.8. A few enterprises in the insurance sector recorded negative growth rate, the worst was Sun Insurance. However, the services of majority of commercialized enterprises have deteriorated. For example, National Electric Power Authority (NEPA) now Power Holding Company of Nigeria (PHCN), Nigerian Telecommunications limited (NITEL) and Nigerian Railways Corporation (NRC) deteriorated in performance after commercialisation. Nigerian Postal Services 
(NIPOST) is the only exemption. Letters now get to anywhere in Nigeria within 3 days as against 14 days before it was commercialized.

Futhermore, Bala (2004) found out that the privatization in Nigeria has been able to replace the public monopoly with private monopoly. However, the major impact of the reform has been in the area of increased competition and efficiency. This were evident in the telecommunication, petroleum and banking sectors. The public sector reforms accounted for majority of the foreign direct investment (FDI) that came to the country between 1999 and 2005.

\section{PRIVATIZATION/COMMERCIALIZATION IN NIGERIA}

The clamoring for privatization/commercialization policy in Nigeria is dated, for instance as far back as 1965. Rweyemanu and Hyden (1975) justified the poor performance of public enterprises in Nigeria and stated that between 1960 and 1965 the Nigerian Railway Corporation alone had 13 enquiries into its activities and in 1965 it had a deficit of N7 million and the World Bank described its finances as disastrous.

At the International scene, the World Bank in 1981 declared for the dismantling of the African Public Enterprises system and submitted that;

"African governments should not only examine ways in which public sector can be operated more efficiently but should also examine the possibility of placing greater reliance on the public sector... what is needed is straight forward acceptance of the principle that under certain circumstances, liquidation of public enterprises may be desirable. (Probsting, 1977)”.

The International Monetary Fund (IMF) has often been recommending privatization/commercialization for developing countries including Nigeria, where the industrial sector and occasionally, key elements in the commercial sector, are heavily dominated by public enterprises. The Fund also argued that "loss-making enterprises have, for many years been a drain in government resources in these Countries. Such enterprises have required direct budgetary transfers or have relied on governmentguaranteed borrowing to finance their cash operating losses”. (Hemming and Mansor, 1988b).

The unprecedented economic problems in Nigeria since early 1980s which led to the accumulation of debts and advise from the international quarters to borrow and accept I.M.F. conditionalities and the subsequent refusal of the loan by Nigerian led to the Structural Adjustment Programme (SAP). It was aimed at restructuring the economy and making it more competitive and efficient. The restructuring of public 
enterprises was an integral part of the Structural Adjustment Programme, in 1986. The actual implementation of commercialization and Privatization started in 1988 with the inauguration of the Technical Committee on Privatization and Commercialization as contained in Decree No. 25 of 1988. Thus, in November 1989 the implementation process of full or partial commercialization began. The parastatals and governmentowned companies were classified into five broad categories; Full or partial privatization, full or partial communication or to remain as public institutions (FGN, 1993).

The Technical Committee on Commercialization and Privatization (TCPC) initially served as the secretariat and implementation of privatization reform. Following enactment of the Public Enterprises Act of 1999, the Bureau of Public Enterprises (BPE) was formed to take over the activities of TCPC. The Act also made provision for the establishment of National Council on Privatization (NCP). The NCP is the lead policy making body in charge of privatization and commercialization in Nigeria.

The Public Enterprises (Privatization and the Commercialization) Act in 1999 empowered the BPE to change emphases from commercialization to encouraging core investors, and promoting foreign investment in the privatization programme. In some cases like the Nigerian Port Authority, BPE employed concessioning rather than outright privatization. Concessioning entails allowing some private company to run ports for five to ten year. The company is automatically granted some level of ownership right.

The exercise of privatization started with commercialization of some enterprises like the Nigeria Railway Corporation (NRC), National Electric Power Authority (NEPA), Nigerian Telecommunication Limited (NITEL) and the postal services. Essentially, privatization programme in Nigeria started with commercialization of public enterprises. This was inevitable because, it was less cumbersome and easier to achieve. It only entails detaching the enterprises from government departments and ministries and made them to be a cost accountability centers as done in the private sector. Government was relieved releasing of subvention to the enterprises. Thereafter, certain enterprises like the Ikoyi Hotel, Federal Palace Hotel, African Petroleum, National oil and Unipetrol were sold to Nigerian.

Kuye (1990) once asserted that the governments of countries such as United Kingdom, France, Canada, Turkey, Nigeria etc. which adopted mixed economy have now accepted the obvious truth that if all, or at least most of the public enterprises were turned over to the private sector they would be better managed and their 
economies would fair much better in terms of the set out goals. For instance, in United Kingdom, the British Prime Minister charted a new economic direction to reduce the high level of inflation, huge domestic debt, high level of unemployment and low growth rate of the national economy, chronic deficit in the British balance of payments position and the depreciation in the value of Pound Sterling. Thus, the privatization of the British economy charted by the Labor Party, led to greater accountability, better factor allocation, ceasing of public subventions of industries.

In Nigeria however, the privatization and commercialization programme has become a major policy instrument, which in addition with other instruments was expected to contribute to the overall attainment of the general macroeconomic goals.

Therefore, the privatization and commercialization programmes in Nigeria was aimed at achieving the following objectives:

- To restructure and rationalize the public sector in order to lessen the dominance of unproductive investments in that sector;

- To re-orientated the enterprise for privatization and commercialization towards a new horizon of performance improvement, viability and overall efficiency;

- To ensure positive returns in public sector investment in commercialization enterprises;

- To check the present absolute reliance of commercially oriented parastatals on the Treasury for funding and to encourage their approach to the Nigerian capital market;

- To initiate the process of gradual cession to the private sector of such publicenterprises those by the nature of their operations and other socialeconomic factors are best performed by the private sector;Creating a favorable investment climate for both local and foreign investors;

- Reduce in the level of internal and external debts; and

- To provide institutional arrangements and operational guidelines that wouldensure that the gains of privatization and commercialization are sustained in the future Decree No. 25 of 1988).

In a more specified manner Commercialization policy is informed by the following reasons:

1. Minimization of Government Interference. The process of commercialization is much more complex. Unlike the privatized enterprises, in commercialization, government would continue to be the sole owner of the enterprises, they would also continue to have financial stake in the enterprises to be commercialized. However, 
the Technical Committee on Privatization and Commercialization (TCPC), now Bureau of Pubic Privatization (BPE), would ensure that all the checks and balances are in place to minimize government interference and to encourage optimum performance by the managers of those enterprises.

2. Commercialized enterprises should adopt commercial orientation and financial self-sufficiency. They are expected to be better managed and to make profit. They are expected to be run like privatized enterprises in future except perhaps in the case of utilities. It should be self sufficient in both its recurrent as well as capital expenditure needs.

Enterprises to be partially commercialized would be expected to operate like the fully commercialized ones in terms of better management and profit orientation but because of the 'public' nature of the goods and services provided by those enterprises and in order to keep the prices of their products or services as low as possible for the public, government would still provide financial grants for the capital projects of the partially commercialized enterprises. They would be expected to earn enough revenue to cover their operating costs.

3. Operational and Management Autonomy.

They are to enjoy considerable operational autonomy and in accordance with the Decree will have the power to operate on strict commercial basis and subject to the regulatory powers of the government, be able to;

- Fix rates, prices and charges for the goods and services provided.

- Capitalize assets

- Borrow money and issue debenture stock; and

- Sue and be sued in their corporate names.

\section{PROBLEMS OF POLICY IMPLEMENTATION}

The idea of privatization is that the state should ensure the supply of services where necessary. It should ensure that essential goods and services are provided but not aimed to be the sole producer or deliverer. Whereas in the past government was seen as often squeezing out market supplies, it is now expected to support their development and promote competition.

The task now is that with the fast incorporation of Nigerian State in to the market oriented system, there seems to be some hindrances to grapple with in actualizing the dreams of public enterprises reform.

According to Obadan and Ayodele (1998), Obadan (2000), Sanusi (2001) the 
relative success in the public enterprises reform has some crucial problems which are economic, political and ideological. These problems are sums up as follows:

1. Socio-political and ideological: Theoretically privatization of Public Enterprises (PEs) has some ideological underpinnings as conceptualized by the classical or neo-classical and the liberal neo-liberal schools of thought. Privatization was seen by some as a carry over of the structural adjustment program and also seen is a caricature of the international capitalist imposition especially the World Bank / IMF. The structural adjustment of the 1980's was seen as an inevitable circumstance that pervaded the world economy order then. The socialist ideologue also sees public enterprises reform as a path towards consolidating capitalism.

2. Uncooperative Attitude of some government officials (Enterprises managers and staff): Some officials were recalcitrant over the policy or privatization as this would undermine the status quo, particularly the supervising ministries. Obadan (2000) argued that the former supervisory ministries mis-conceived the program as a way to reduce their power as the affected PEs will be insulated from all ministerial controls and interference, and somehow silently opposed to the policy arrangements.

Similarly managers and staff of these privatized PEs are against the reform as it would undermine their position. Some of these criticisms overtly or covertly may have devastating implication on the program.

1. Weak market alternatives: As applicable to poor developing countries, Nigeria has less mature formal business sectors, with higher start up cost, less capacity to invest, and less exposure to competition.

2. Geo-political and income-group spread: The enabling decree laid emphasize on equity in the spread of shareholding. But contrarily there were marked imbalances in equity shareholders distribution among income groups and the different segments of the society. Some income-groups or geo-political entity tends to have cornered the market.

3. Government capacity: Closely related to the attitude of the public officials and managers of PEs over the delays in the implementation of PE reforms has to do with whether the government has the administrative and political ability to undertake its new roles. Government must have the capacity not only to make initial diagnoses and assessments to decide on policy implementation and also to administer the states roles once PEs reforms have been established. 
4. Poor funding of the National Committee on Privatization and Bureau of Public enterprises: The essential economic reform mandate of the Bureau and the various NCP sector steering committees is threatened by poor funding.

According to Okutaoluibe (2002) who articulated the view point of the Director General of BPE in a press briefing in Abuja on 4th June 2002, revealed that

"the National Assembly appropriated only N406,056,000 to the BPE in the 2002 budget as against the N1.6 billion proposed. A breakdown of the BPE proposal showed that out of the N0.6 billion proposed as the personnel budget only N166 million was appropriated. In the recurrent expenditure, N240 million was appropriated out of the $N 329$ million proposed. While no approvals were received in the capital expenditure, NCP committee, Advertisement, Bilateral commissions and counterpart funding”.

In 2001 budget, NCP/BPE made budget proposal of N1.4 billion, the sum of N520 million was approved for it. This 61 percent cut grossly affected the work of thecommittees and the conclusion of some of its sector reform activities.

1. The Problem of inaccessibility to credit:

Many prospective equity holders did not have enough funds to process their application forms, contrary to the expectations of government. Perceiving problem of financial limitations, government directed all licensed commercial banks to extend to all interested persons. In spite of this directive, banking system did not respond favorably due to what they called “operational lapses". The financial problem thus dampened the enthusiasm, particularly of paid workers whose salaries are not high enough to cope with the financial requirement to benefit from the policy. However, it may therefore be necessary for Employer's Association to provide assistance for their employees, in terms of share purchase loans that will relief and relax the high tension of workers with respect to this program.

2. Institutional Investors versus Small Individual Investors:

On many occasions there were reports of over-subscription in the shares for offer of sales. This, in most cases, arose from the intervention of institutional investors to broaden their investment portfolios. This intervention, incidentally, obstructed the chances of small individual investors in getting the quantities of equity shares they desired (Obadan and Ayodele, 1998). 


\section{CONCLUSION}

In conclusion, if privatization must of necessity bring forth the desired benefits it has to be viewed not as an end itself, but as a means to get government interested in fostering a new division of labour between the public and private sectors in order to increase the efficiency and contribution to development of both sectors. Therefore, the success of privatization should be judged not in terms of the sale or contract itself or the price paid to government, or even the survival or expansion of the enterprise sold, but rather, on the basis of whether there are net benefits to the economy (Shirley 1998). Privatization must result in better service at lower prices as desired by consumers who, oftentimes, are not much bothered about economic philosophies. If privatization does not bring tangible benefits in one form or another, the opponents of privatization who argue that the benefits are not worth the cost would feel justified. And, indeed, as the FGN (1993) also correctly observed the primary argument for privatization and commercialization is of course, that the efficiency and profitability of the investments will improve after the exercise. At the end of the day, it is perhaps only a clear demonstration of such improvement that will convince people who hold such (opposing) views.

The on going privatization is a good policy measure, which the Government must pursue with vigor. The privatization equity loan program of government should be reactivated and made available to the poor and civil servant.

\section{REFERENCES}

Ajakaiye, O. (1990). Public Enterprises Policies in Nigeria. Ibadan: Nigeria Institute of Social Economic Research.

Ayodele, S.(1988). Privatization and Commercialization of Public Enterprises and their Implications. In Adedotun P. (ed.) Economic Policy and Development in Nigeria Ibadan, Nigeria, Nigeria Institute of Economic Research Ibadan.

Bala, J.J.(2004). The Nigerian Privatisation Programme: Strategies \& Timeliness 2003- 2007. NESG Policy Dialogue Series, 3( 2) , 11-28.

Efange, P. (1987). "An overview of Public and Private Enterprises in Africa: Role, Status, Scope, Performance and Challenges for Implementing the Lagos Plan of Action" In Proceedings of the Africans Association of Public Administration and Management. Sixth Round Table Conference held in Blantyre, Public Enterprises Performance and the Privatization Debate: A Review of the option for Africa. India: Vikas Publishing House PVT LTD India. 
Federal Republic of Nigeria FGN (1988). Privatisation and Commercialisation Decree No. 25 of 1988.

Federal Republic of Nigeria (1993). The Presidency Technical Committee on Privatization and Commercialization, Final Report Vol.1 [Main Report]

Hanson, A. H. (1972). Public Enterprises and Economic Development. London: Toutledge and Kegan Paul.

Hemming, R., and A. Mansor. (1988). Privatisation and Public Enterprises'. IMF Occasional Paper (56): 1-22. Washington, DC: International Monetary Fund.

Hemming, R. E. and A. Mansor (1988b). Is Privatization the Answer? Finance and Development, 25(3), 31-33.

Kalu, I. K. (1999, December, 29). Modalities for Privatizing State Enterprises. The Guardian.

Kuye, O. A. (1990). Problems and Prospects of Nigeria's Privatization and Commercialization Programme. The Quarterly Journal of Administration, 25 ( 9), 49-73.

Laleye, O. M. (1985). The Role of Public Enterprises in the Development of Nigeria. Unpublished Ph.D. Thesis, University of Ife, Ile-Ife.

Nellis J. (1986). Public Enterprises in Sub-Saharan Africa. Washington, D.C. World Bank.

Obadan, M. \& S. Ayodele (1998). Commercialization and Privatization Policy in Nigeria. Ibadan: National Centre for Economic Management and Administration.

Obadan, M. I. (2000). Privatization of Public Enterprises in Nigeria. Issues and Conditions for success in the Second Round. Ibadan: National Centre for Economic Management and Administration.

Ogundipe V. (1986, January 7). The inevitability of Privatization. The Guardian, pp.7. Okutaoluibe, C. (2002, June 13). Poor Funding May Cripple Privatization. The Comet, pp. 21.

Ostrum, V. and E. Ostrum(1991) Public Choice: A Difference Approach to the Study of Public Administration. Public Administration Review, 31, 302-316.

Okigbo, P.(1998 May 4). A Layman’s Guide to privatization. Daily Champion, pp 24. Probsting, K. (1977). Thought About a public Service Balance Sheet. Annuals of Public and Co-operative Economy, 48(1), 45-53.

Rondinelli, D. A. \& Iacono Marx (1996). Strategic Management of Privatization. A Framework for Planning and Implementation. Public Administration and Development, 16, 247. 
Rweyemanu, A. and G. Hyden (1975). A Decade of public Administration in Africa.

Nairobi, Kenya, East African Literature Review, Bureau, Nairobi.

Samuelson, P. A. (1980). Economics. New York: McGraw Hill Book Company.

Sanusi, J. O. (2001). Challenges, Problems and Prospects of Privatization in

Developing Economy. Journal of the Institute of Stockbrokers, 2 (11), 4-9.

Shirley (1998). Trends in Privatization. Economic Reform Today, 1, 8-10.

Sosna, S. A. (1983). Public Enterprises in Developing Countries, Legal Status. Moscow, Progress Publishers.

Ugorji, E. C. (1995). Privatization / Commercialization of State-owned Enterprises in Nigeria: Strategies for Improving the Performance of the Economy. Comparative Political Studies, 27(4), 537-560.

World Bank (1991). The Reform of Public Sector Management. Washington D.C. Policy and Research Series No. 18. 


\section{APPENDIX}

\section{Prices of selected Privatized Enterprises as at September, 2006}

\begin{tabular}{|l|c|c|c|c|c|}
\hline \multicolumn{1}{|c|}{ Privatized Company } & $\begin{array}{c}\text { Date of } \\
\text { Offer } \\
(1)\end{array}$ & $\begin{array}{c}\text { Offer } \\
\text { Price (N) } \\
(2)\end{array}$ & $\begin{array}{c}\text { Market Price } \\
\text { as at 7/9/06 } \\
(3)\end{array}$ & $\begin{array}{c}\text { \% Change } \\
(4)\end{array}$ & $\begin{array}{c}\text { Capital } \\
\text { Appreciation (N) } \\
(5)=(3)-(2)\end{array}$ \\
\hline $\begin{array}{l}\text { National Oil } \\
\text { Plc.(conoil) }\end{array}$ & $8 / 5 / 89$ & 2.00 & 69.5 & 3375 & 67.5 \\
\hline African Petroleum Plc & $27 / 2 / 89$ & 1.90 & 40 & 2005 & 38.1 \\
\hline $\begin{array}{l}\text { Unipetrol Nig. } \\
\text { Plc.(Oando) }\end{array}$ & $27 / 5 / 91$ & 2.00 & 78.8 & 3840 & 76.8 \\
\hline UNIC Ins. Plc. & $24 / 7 / 89$ & 1.20 & 1.8 & 50 & 0.6 \\
\hline Crusader Ins. Plc. & $6 / 11 / 89$ & 1.30 & 2.1 & 62 & 0.8 \\
\hline Niger Ins. Plc. & $6 / 11 / 89$ & 1.30 & 2.6 & 100 & 1.3 \\
\hline WAPIC Plc. & $6 / 11 / 89$ & 1.10 & 3.9 & 255 & 2.8 \\
\hline BAICO Plc. & $6 / 11 / 89$ & 1.10 & 1.6 & 46 & 0.5 \\
\hline $\begin{array}{l}\text { Ashaka Cement Co. } \\
\text { Plc. }\end{array}$ & $5 / 3 / 90$ & 1.20 & 50.7 & 3438 & 41.25 \\
\hline Benue Cement Co. Plc. & $20 / 8 / 90$ & 0.90 & 21.8 & 2322 & 20.9 \\
\hline Flour Mills Nig. Plc. & $3 / 1 / 89$ & 0.80 & 50.5 & 643 & 49.7 \\
\hline NIYAMCO Nig. Plc & $12 / 2 / 90$ & 0.70 & 2.16 & 209 & 1.46 \\
\hline Okomu Oil & $2 / 7 / 90$ & 0.90 & 37.5 & 4067 & 36.6 \\
\hline AIICO Ins. Plc & $6 / 11 / 89$ & 1.65 & 1.9 & 15 & 0.25 \\
\hline Guinea Ins. Plc. & $6 / 11 / 89$ & 0.80 & 0.6 & -25 & -0.2 \\
\hline $\begin{array}{l}\text { Law, Union \& Rock } \\
\text { Ins. Plc }\end{array}$ & $6 / 11 / 89$ & 0.95 & 1.5 & 37 & .55 \\
\hline NEM Ins. Plc & $6 / 11 / 89$ & 1.15 & 1.1 & -4.3 & -0.05 \\
\hline Prestige Assurance Plc & $3 / 10 / 89$ & 1.15 & 2.7 & -135 & 1.55 \\
\hline Royal Exchange & $3 / 10 / 89$ & 1.75 & 2.6 & 48.57 & 0.85 \\
\hline Sun Ins. Plc & $3 / 10 / 89$ & 1.25 & 0.59 & -52 & -0.66 \\
\hline Afribank Nig. Plc & $11 / 1 / 93$ & 1.20 & 7.5 & 525 & 6.3 \\
\hline First Bank Plc & $6 / 1192$ & 2.00 & 42 & 200 & 40 \\
\hline UBA Plc & $10 / 5 / 93$ & 1.80 & 22 & 1122 & 20.2 \\
\hline Union Bank Plc & $7 / 12 / 92$ & 1.00 & 27 & 2600 & 26 \\
\hline $\begin{array}{l}\text { Cement Co. of } \\
\text { Northern Nig. Plc }\end{array}$ & $2 / 3 / 92$ & 1.00 & 12.3 & 1130 & 11.3 \\
\hline Union Dicon Salt Plc & $14 / 1 / 93$ & 2.00 & 3.4 & 0.7 & 1.4 \\
\hline Saice: Obadan and & Ays & & & \\
\hline
\end{tabular}

Source: Obadan and Ayodele(1998) and BusinessDay( 2006). 